\title{
Differential Effects of Post-Flowering Drought Stress on Growth and Yield of the Basic Generations of Two Common Bean (Phaseolus Vulgaris L.) Populations
}

\author{
Abebe Hinkossa ${ }^{1^{*}}$, Setegn Gebeyehu ${ }^{2}$, Habtamu Zelleke ${ }^{3}$ \\ ${ }^{1}$ Bule Hora University, Post Box No: 144, Bule Hora, Ethiopia \\ ${ }^{2}$ National Bean Research Program, Melkassa Agricultural Research Center, \\ Post Box No: 436, Adama, Ethiopia \\ ${ }^{3}$ Haramaya University, Post Box No: 76, Haramaya, Ethiopia
}

\begin{tabular}{|c|c|}
\hline & \\
\hline \multirow{10}{*}{$\begin{array}{l}\text { Information on the response of basic generations of a population to drought stress may } \\
\text { help in designing effective breeding procedure and identification of selection criteria that } \\
\text { can be used to develop suitable cultivars. This study was carried out to assess the } \\
\text { differential effects of drought stress initiated at flowering stage on the growth, physiological } \\
\text { and yield related traits of six basic generations of two common bean populations made of } \\
\text { crosses between pairs of drought resistant and susceptible parents (Roba-1 X SER-16; } \\
\text { Melka-Dima X SAB623). On average, the stress imposed reduced the various characters } \\
\text { examined in the range of } 3 \% \text { (pod length) to } 28 \% \text { (seed yield). Canopy temperature and } \\
\text { chlorophyll content, however, increased in response to the stress. When generations of the } \\
\text { two populations were compared, those obtained from Melka-Dima X SAB-623 were more } \\
\text { sensitive to drought than Roba } 1 \text { X SER-16 counterparts. In both crosses, the drought } \\
\text { susceptible parents (Roba } 1 \text { and Melka-Dima) had the highest drought-induced reduction } \\
\text { in growth, stomatal conductance and all yield related traits whereas P1, F1 and BC1 } \\
\text { exhibited better performance under drought stress for the different characters studied. } \\
\text { Under drought, F1 generation produced higher seed yield than F2 and the two parents, } \\
\text { indicating the presence hetrosis under the stress condition. With geometric means of } 3722 \\
\text { and } 4077 \text {, F1 and P1 were found to be the most drought resistant generations in Roba } 1 \mathrm{X} \\
\text { SER-16 and Melka-Dima X SAB-623 crosses, respectively. Superior performance under } \\
\text { drought stress of these generations was associated with the maintenance of higher } \\
\text { stomatal conductance, leaf area and aboveground biomass as well as greater ability to } \\
\text { remobilize biomass to reproductive sinks (pods and seeds). }\end{array}$} & Received : 22-01-2013 \\
\hline & : 25-03-2013 \\
\hline & Accepted : 29-03-2013 \\
\hline & Keywords: \\
\hline & Common Bean \\
\hline & Drought Indices \\
\hline & Drought Resistance \\
\hline & d Yield \\
\hline & \\
\hline & \\
\hline
\end{tabular}

\section{INTRODUCTION}

Drought stress is an endemic problem throughout the world and the common bean production under water limiting conditions is common (Munoz-Perea et al., 2006). The effects of drought on common beanare dependent on the intensity, type, duration of the stress and growth stages affected (Munoz-perea et al., 2006). In dry bean, excessive abortion of flowers, young pods, and seeds occurs because of drought stress during pre-flowering (10-12 days before an thesis) and reproductive periods. Moderate to severe drought stress reduced biomass and seed yield (from 20 to $90 \%$ ), harvest index, number of pods and seeds, seed weight, and days to maturity (Nunez-Barrios et al., 2005). Whether yield under stress is compatible or not with maximum yield potential is an open question for different crops (Blum, 2005). In the case of beans some materials that were essentially selected for drought resistance also have better yield potential in favorable conditions, and frequently within a shorter growth cycle (Beebe et al., 2008). Reproductive development is particularly sensitive to drought, resulting in increased 
Abebe Hinkossa et al.,

abortion and abscission of buds, flowers and pods, and a reduction in seed yield (MunozPerea et al., 2006). Due to the occurrence of terminal drought stress in production areas worldwide, germ plasm evaluation in common bean is commonly conducted through the application of drought stress between preflowering and physiological maturity.

A water deficiency during any growth stages of bean species often results in a loss of yield. Therefore, it is important to elucidate the drought tolerance mechanisms of these species in order to improve its agronomic performances and to obtain more resistant cultivars (Subbarao et al., 1995). On the other hand, understanding the physiological and biochemical mechanisms providing these common bean cultivars with drought tolerance is very important in terms of developing selection and breeding strategies. Drought resistance is a complex trait, expression of which depends on action and interaction of different morphological, physiological and biochemical characters (Mitra 2001).Genotypic differences for drought resistance have been reported for common bean (Abebe et al., 1998). The most effective selection criterion, among various morphological, physiological, phenological, yield, and yield related traits, for identifying drought resistant genotypes was mean seed yield (the arithmetic and geometric) of drought stress and non-stress environments (Abebe et al., 1998). In dry bean, drought resistance was reported in the races Durango, Mesoamerica, and Jalisco (Teran and Singh 2002). The highest level of drought resistance among these races occurs in the race Durango, which originated in the semiarid central and northern highlands of Mexico (Munoz-Perea et al., 2006).

Physiological trait based breeding approach has merit over breeding for yield per se because it increases the probability of crosses resulting in additive gene action (Reynolds and Trethowan, 2007). The process of incorporating new genetic diversity can be accelerated with suitable earlygeneration selection tools that enable the best progeny to be identified before costly yield trials are run. The development of bean genotypes that are more resistant to water stress is a practical and economical approach to lessen the negative effects of drought on the productivity of the crop (Ramirez-Vallejo and Kelly, 1998). For a successful breeding program, the availability of genetic variability and knowledge of gene action to improve drought tolerance are essential, otherwise choice of breeding methods used may not result in appreciable improvement. Studies
Sci. technol. arts Res. J., Jan-Mar 2013, 2(1): 22-31

aimed at elucidating response to drought stress of basic generations of wheat (Munir et al., 2007) and common bean (Khaghani et al., 2012) demonstrated significant differences among generations for different traits and the type of gene action to vary with the traits, crosses and treatments. Effective breeding procedure and selection criteria that can be employed to develop drought tolerant common bean cultivars suitable for the moisture stressed Central Rift Valley and regions with similar agro-ecology of Ethiopia is lacking. The study was carried out to assess the differential effects of drought stress imposed at flowering stage on the growth, physiological and yield related traits of six basic generations of common bean populations.

\section{MATERIALS AND METHODS}

\section{Site Description}

The field experiment was carried out at Melkassa Agricultural Research Center (MARC) which is found in the Central Rift Valley of Ethiopia. The center is located at $8^{0} 24^{\prime} \mathrm{N}$ latitude and $39^{\circ} 21^{\prime} \mathrm{E}$ longitudes at an altitude of 1550 masl. The climate of the area is characterized as semi-arid with mean monthly maximum and minimum temperature of $33{ }^{\circ} \mathrm{C}$ and $10.8{ }^{\circ} \mathrm{C}$, respectively. The area is characterized by low and erratic rainfall with unimodal pattern of distribution. The soil is sandy clay loam (Cambisol).

\section{Experimental Materials}

The parents include two drought resistant (SER- 16 and SAB-623) and two susceptible (Roba-1 and Melka-Dima) common bean genotypes. Roba-1 is a small seeded commercial cultivar sensitive to drought stress. SER-16 is small red seeded advanced breeding line from CIAT with good degree of resistance to drought. Melka-Dima is another drought susceptible commercial cultivar with medium size seed. SAB6-23 is an advanced breeding line from CIAT with medium seed size and good level of tolerance to drought. Initially, two singlecrosses were made using the four parents: Roba- $1 X$ SER-16 and Melka-Dima X SAB-623. The experimental material consisted of six generations for each cross. These were parents $\left(P_{1}\right.$ and $\left.P_{2}\right)$, the first and second filial generation $\left(F_{1}\right.$ and $\left.F_{2}\right)$ and back crosses $\left(B C_{1}=P_{1} \times F_{1}\right.$ and $\left.\mathrm{BC}_{2}=\mathrm{P}_{2} \times \mathrm{F}_{1}\right)($ Table 1).

\section{Experimental Design and Treatments}

The six treatments (P1, P2, F1, F2, BC1, and $B C 1)$ for each population were planted in split plot design with watering regime as a main plot and generations were assigned to sub plots. 
Table 1: List of parents and crosses produced.

\begin{tabular}{ccc}
\hline Generation & $\begin{array}{c}\text { Parents and crosses } \\
\text { (population 1) }\end{array}$ & $\begin{array}{c}\text { Parents and crosses } \\
\text { (population 2) }\end{array}$ \\
\hline $\mathbf{P}_{1}$ & SER-16 & SAB-623 \\
$\mathbf{P}_{2}$ & Roba-1 & Melka-Dima \\
$\mathbf{F}_{1}$ & Roba-1XSER-16 & Melka-Dima X SAB-623 \\
$\mathbf{F}_{2}$ & Roba-1XSER-16 & Melka-Dima X SAB-623 \\
$\mathbf{B C} \mathbf{C}_{1}$ & SER-16X (Roba-1X SER-16) & SAB-623 X (Melka-Dima X SAB-623) \\
$\mathbf{B C} \mathbf{C}_{2}$ & Roba-1X(Roba-1 X SER-16) & Melka-Dima X(Melka-Dima XSAB-623) \\
\hline
\end{tabular}

Overall, twelve generations $(2 \mathrm{P} 1,2 \mathrm{P} 2,2 \mathrm{~F} 1,2$ $\mathrm{F} 2,2 \mathrm{BC} 1$ and $2 \mathrm{BC} 2)$ were grown under two contrasting watering regimes, non-stress (NS) and drought-stress (DS) and the treatments were replicated three times. Planting was done late in season (4th week of September 2010) to expose the drought stressed treatments to terminal stress when the main season rains cease. The nonstressed treatments received supplemental irrigation until physiological maturity whereas the stressed treatments were subjected to terminal drought stress by withholding application of irrigation at flowering stage. Soil moisture measurement (centi bars) was taken using water mark (IRROMETER CAMPANY, INC). Since the non-segregating generation represents the homozygous population while segregating generation represents heterozygous population, the number of plants used for the different generations was varied. Accordingly, there were two rows per plot for $\mathrm{P}_{1}, \mathrm{P}_{2}, \mathrm{~F}_{1}, \mathrm{BC}_{1}$ and $\mathrm{BC}_{2}$ generations and four rows per plot for $F_{2}$ generation. The row length was $2 \mathrm{~m}$ and the rows were kept at $0.6 \mathrm{~m}$ apart. Within row spacing (distance between plants) was $10 \mathrm{~cm}$. Fertilizers were applied at planting using the rate of $46 \mathrm{P}_{2} \mathrm{O}_{5}$ $\mathrm{kg} \mathrm{ha}^{-1}$ in the form of DAP and other crop management was carried out as recommended for the area.

\section{Data Collected}

Pod length, plant height, number of pods per plant, seeds per pod and seed yield per plant were determined on ten and five randomly selected plants for $F_{2}$ and the other five generations, respectively. Leaf area $\left(\mathrm{LA}, \mathrm{cm}^{2}\right)$ offive plants per treatment was measured using a non-destructive method developed as standard system for the evaluation of bean leaf area (Assefa, 1994).Seed yield per hectare was obtained by converting plot yield and adjusting seed moisture content at $10 \%$. Above Ground Biomass (AGB, gm plant ${ }^{-1}$ ) was considered as weight of above ground parts (stem + leaves + pod wall + seed) at harvest after drying for $48 \mathrm{~h}$ at $85{ }^{\circ} \mathrm{C}$ randomly selected plants. Harvest Index
$(\mathrm{HI})$ was determined as proportion of seed weight to the above-ground biomass at harvesting dry weight (stem + leaves + pod wall + seed) at harvest $\times 100$.

For all physiological parameters, measurements were taken twice from three plants per plot on three fully expanded upper canopy leaves. Leaf chlorophyll content (SPAD value) was measured by using a non-destructive, hand-held chlorophyll meter (SPAD-502 chlorophyll meter, Minolta Camera Co., Ltd., Japan). Canopy temperature $\left(\mathrm{CT} ;{ }^{\circ} \mathrm{C}\right)$ was considered as the difference in temperature between the leaf canopy and the surrounding air temperature measured using an infrared thermometer (Telatemp model AG-42D, Telatemp CA, USA). Stomatal conductance $\left(\mathrm{mmol} \mathrm{m} \mathrm{m}^{-2} \mathrm{~s}^{-1}\right.$ ) for water vapor was measured using a portable leaf porometer (leaf porometer, Decagon Devices INC). The photo system II quantum yield (quantum yield, QY) was measured by using a non-destructive, hand-held Qy meter (Fluorpen, FP100, Photo systems Instruments).

Seed yield based geometric mean (GM) calculated as $\mathrm{GM}=(\mathrm{Ys} \times \mathrm{Yi}) 1 / 2$ where $Y s$ was the mean seed yield of a genotype under drought stress and $\mathrm{Yi}$ was the mean seed yield of the genotype grown under non-stress. Drought Intensity Index (DII) and Drought Sensitivity (Susceptibility) Index (DSI) for seed yield were generated following the methods used by Ramirez-Vallejo and Kelly (1998) and Fischer and Maurer (1978), respectively. Percent reduction (PR) was calculated as [(mean value of non-stress traits) - (mean value of drought stress trait)]/mean value of non-stress.

\section{Data Analysis}

Data were analyzed using split plot analysis of variance (ANOVA) (Gomez and Gomez 1984) using SAS computer software (SAS, 2004) 9.0 version. Mean separation was conducted using least significance difference (LSD) at $5 \%$ probability level. 
Abebe Hinkossa et al.,

\section{Effect of Drought Stress on Growth Characteristics}

Main effects due to watering regime and genotype (generation) were significant forall growth related traits (plant height, pod length, leaf area and above ground biomass) inRoba-1 $X$ SER-16 as well as Melka-Dima X SAB-623
Sci. technol. arts Res. J., Jan-Mar 2013, 2(1): 22-31

crosses. The interaction terms were also significant for all traits except plant height in both crosses. Relative to the control treatments, drought stress initiated at flowering stage caused $8,3,4$ and $22 \%$ reductions in plant height, pod length, leaf area and above ground biomass per plant, respectively (Table 2 ).

Table 2: Growth characteristics of six generations of two common bean crosses grown under drought stress and non-stress conditions at Melkassa, Central Rift Valley of Ethiopia.

\begin{tabular}{|c|c|c|c|c|c|c|c|c|c|}
\hline \multirow[b]{2}{*}{ Cross } & \multirow{2}{*}{$\begin{array}{l}\text { Gene- } \\
\text { ration }\end{array}$} & \multicolumn{2}{|c|}{ PH } & \multicolumn{2}{|c|}{ PL } & \multicolumn{2}{|c|}{ LA } & \multicolumn{2}{|c|}{ AGB } \\
\hline & & NS & DS & NS & DS & NS & DS & NS & DS \\
\hline \multirow[b]{4}{*}{ Roba-1 } & $\mathrm{P}_{1}$ & $35.7^{c}$ & $35.2^{\mathrm{bc}}$ & 10.3 & 10.3 & $81.1^{c}$ & $87.7^{\mathrm{ab}}$ & $276.4^{b}$ & $234.1^{\mathrm{ab}}$ \\
\hline & $\mathrm{P}_{2}$ & $44.4^{\mathrm{a}}$ & $37.0^{\mathrm{ab}}$ & 10.5 & 10.1 & $95.5^{\mathrm{a}}$ & $72.5^{\mathrm{C}}$ & $328.3^{\mathrm{a}}$ & $211.8^{\mathrm{b}}$ \\
\hline & $F_{1}$ & $42.0^{\mathrm{a}}$ & $38.5^{\mathrm{a}}$ & 11.1 & 10.6 & $92.5^{\mathrm{a}}$ & $94.1^{a}$ & $295.5^{\mathrm{b}}$ & $247.5^{a}$ \\
\hline & $\mathrm{F}_{2}$ & $37.7^{\mathrm{bc}}$ & $34.5^{\mathrm{c}}$ & 10.0 & 9.4 & $77.2^{\mathrm{C}}$ & $74.4^{\mathrm{C}}$ & $236.3^{c}$ & $178.9^{c}$ \\
\hline$x$ & $\mathrm{BC}_{1}$ & $38.3^{b c}$ & $34.8^{\mathrm{C}}$ & 10.2 & 9.8 & $78.3^{c}$ & $84.4^{\mathrm{b}}$ & $234.4^{c}$ & $226.3^{\mathrm{ab}}$ \\
\hline \multirow[t]{5}{*}{ SER-16 } & $\mathrm{BC}_{2}$ & $39.0^{\mathrm{b}}$ & $37.4^{\mathrm{a}}$ & 10.2 & 9.6 & $86.1^{\mathrm{b}}$ & $75.0^{\mathrm{C}}$ & $278.1^{\mathrm{b}}$ & $215.1^{\mathrm{b}}$ \\
\hline & Mean & 39.5 & 36.2 & 10.4 & 9.9 & 85.13 & 81.38 & 274.8 & 219 \\
\hline & $\operatorname{LSD}_{0.05}$ & 2.9 & 2.14 & ns & ns & 3.96 & 6.82 & 33.14 & 26.08 \\
\hline & CV & 4.12 & 3.24 & 4.74 & 5.89 & 2.55 & 4.61 & 6.63 & 6.55 \\
\hline & $P_{1}$ & $38.0^{d}$ & $37.0^{\mathrm{C}}$ & $8.74^{\mathrm{bc}}$ & $7.93^{b}$ & $79.1^{\mathrm{bc}}$ & $75.8^{\mathrm{a}}$ & $301.9^{b}$ & $252.2^{\mathrm{a}}$ \\
\hline \multirow{3}{*}{$\begin{array}{l}\text { Melka- } \\
\text { Dima }\end{array}$} & $\mathrm{P}_{2}$ & $51.7^{a}$ & $43.8^{\mathrm{a}}$ & $9.55^{\mathrm{a}}$ & $7.58^{\mathrm{b}}$ & $83.3^{\mathrm{ab}}$ & $65.8^{\mathrm{c}}$ & $335.8^{\mathrm{a}}$ & $141.7 \mathrm{e}$ \\
\hline & $F_{1}$ & $48.0^{\mathrm{ab}}$ & $44.7^{\mathrm{a}}$ & $9.31^{\mathrm{ab}}$ & $8.67^{\mathrm{a}}$ & $85.8^{\mathrm{a}}$ & $76.1^{a}$ & $324.1^{\mathrm{ab}}$ & $202.5^{\mathrm{bc}}$ \\
\hline & $\mathrm{F}_{2}$ & $43.3^{c}$ & $38.3^{c}$ & $8.18^{C}$ & $7.26^{b}$ & $69.1^{d}$ & $66.6^{c}$ & $251.2^{c}$ & $191.3^{c}$ \\
\hline $\mathrm{X}$ & $\mathrm{BC}_{1}$ & $45.0^{\mathrm{bc}}$ & $41.5^{\mathrm{b}}$ & $8.67^{\mathrm{bc}}$ & $7.76^{b}$ & $75.5^{\mathrm{c}}$ & $72.7^{\mathrm{ab}}$ & $318.2^{\mathrm{ab}}$ & $223.7^{\mathrm{b}}$ \\
\hline SAB- & $\mathrm{BC}_{2}$ & $46.1^{b c}$ & $43.3^{\mathrm{a}}$ & $8.86^{b}$ & $7.38^{b}$ & $79.1^{b c}$ & $66.6^{\mathrm{bc}}$ & $237.8^{c}$ & $167.1^{d}$ \\
\hline \multirow[t]{3}{*}{623} & Mean & 45.35 & 41.45 & 8.88 & 7.76 & 78.7 & 69.82 & 294.8 & 197.59 \\
\hline & $\operatorname{LSD}_{0.05}$ & 3.94 & 1.71 & 0.67 & 0.67 & 5.92 & 6.19 & 26.35 & 23.8 \\
\hline & CV & 4.77 & 2.27 & 4.16 & 4.77 & 4.13 & 4.87 & 4.91 & 6.62 \\
\hline
\end{tabular}

PH plant height, $\mathrm{cm}$; PL pod length, $\mathrm{cm}$; LA leaf area, $\mathrm{cm}^{2}$; AGB above ground biomass, $\mathrm{g}_{\text {plant }}{ }^{-1}$; $\mathrm{CV}$ coefficient of variation; LSD least significance difference; NS non-stress; DS drought stress; P1 parent 1; P2 parent 2; F1 first filial generation; F2 second filial generation; BC1 back cross 1; BC2 back cross 2; ns not significant; Means in the same column for each cross followed by similar letter are not different according to LSD test at $5 \%$ level of probability.

Among the generations, F1 had the highest plant height, leaf area and above ground biomass in Roba 1 X SER-16 cross and for all traits except above ground biomass in Melka-Dima X SAB-623 cross under drought stress and non-stress conditions (Table 2). In both crosses, the highest drought-induced reduction in growth was encountered by $\mathrm{P} 2$, drought susceptible parents. Leaf area of Roba 1 and MelkaDima decreased by 24 and $21 \%$, respectively due to the drought stress imposed. On the contrary, drought induced reductions on most of the growth related characteristics were lower in P2 (the drought resistant parents) of both crosses although $\mathrm{BC} 1$ in the first cross and F2 in the second cross demonstrated consistent performance over the two watering regimes in above-ground biomass and leaf area, respectively. On overall basis, growth of the various generations ofMelka-Dima
X SAB-623 appeared to be more sensitive to drought than the Roba 1 X SER-16 cross counterparts (Table 2). For instance, drought induced above ground biomass reduction ranged from 3.5 (BC1) to $35.5 \%$ (P2) in Roba 1 X SER16 cross compared with 16.5 (P1) to $57.8 \%$ (P2) in Melka-Dima X SAB-623.

\section{Effect of Drought Stress on Physiological Characteristics}

Main effects due to watering regime and genotype (generation) were significant forstomatal conductance, canopy temperature and quantum yield. However, the difference in leaf chlorophyll content was significant only between the watering regimes and not among the generations of both crosses. Likewise, the watering regime $\mathrm{x}$ generation interaction terms 
Abebe Hinkossa et al.,

was significant for all traits except chlorophyll content. Whereas drought stress reduced stomatal conductance and quantum yield of all the six generations of the two crosses, canopy
Sci. technol. arts Res. J., Jan-Mar 2013, 2(1): 22-31

temperature and chlorophyll content tended to rise in response to the drought stress imposed (Table 3).

Table 3: Physiological characteristics of six generations of two common bean crosses grown under drought stress and non-stress conditions at Melkassa, Central Rift Valley of Ethiopia.

\begin{tabular}{|c|c|c|c|c|c|c|c|c|c|}
\hline \multirow{2}{*}{ Cross } & \multirow{2}{*}{$\begin{array}{l}\text { Gene- } \\
\text { ration }\end{array}$} & \multicolumn{2}{|c|}{ gs } & \multicolumn{2}{|c|}{ CT } & \multicolumn{2}{|c|}{ Qy } & \multicolumn{2}{|c|}{ Chl } \\
\hline & & NS & DS & NS & DS & NS & DS & NS & DS \\
\hline \multirow{9}{*}{$\begin{array}{l}\text { Roba-1 } \\
\quad X \\
\text { SER-16 }\end{array}$} & $P_{1}$ & $268.3^{c}$ & $234.9^{b}$ & $16.5^{\mathrm{ab}}$ & $18.1^{\mathrm{c}}$ & $0.430^{\mathrm{b}}$ & $0.427^{b}$ & 38.77 & 41.3 \\
\hline & $\mathrm{P}_{2}$ & $284.1^{\mathrm{b}}$ & $212.3^{\mathrm{de}}$ & $17.0^{\mathrm{a}}$ & $19.9^{a}$ & $0.439^{\mathrm{ab}}$ & $0.388^{\mathrm{cd}}$ & 43.2 & 43.89 \\
\hline & $F_{1}$ & $296.5^{\mathrm{a}}$ & $244.2^{\mathrm{a}}$ & $15.6^{\mathrm{bc}}$ & $18.8^{\mathrm{bc}}$ & $0.476^{\mathrm{a}}$ & $0.461^{a}$ & 41.36 & 43.64 \\
\hline & $\mathrm{F}_{2}$ & $230.0^{d}$ & $211.2 \mathrm{e}$ & $16.6^{\mathrm{ab}}$ & $20.6^{a}$ & $0.390^{\circ}$ & $0.381^{d}$ & 40.9 & 42.03 \\
\hline & $\mathrm{BC}_{1}$ & $261.2^{c}$ & $225.4^{\mathrm{c}}$ & $14.8^{\mathrm{c}}$ & $19.7^{\mathrm{ab}}$ & $0.423^{b c}$ & $0.418^{b}$ & 38.4 & 43.57 \\
\hline & $\mathrm{BC}_{2}$ & $283^{\mathrm{b}}$ & $220.0^{\text {cd }}$ & $16.8^{\mathrm{ab}}$ & $19.8^{\mathrm{ab}}$ & $0.431^{\mathrm{b}}$ & $0.409^{b c}$ & 42.94 & 43.41 \\
\hline & Mean & 270.5 & 224.9 & 16.3 & 19.5 & 0.43 & 0.41 & 40.9 & 42.9 \\
\hline & $\operatorname{LSD}_{0.05}$ & 12.36 & 7.55 & 1.21 & 1.07 & 0.04 & 0.02 & ns & ns \\
\hline & CV & 2.5 & 1.85 & 4.07 & 3.029 & 4.72 & 3.04 & 5.64 & 3.42 \\
\hline \multirow{9}{*}{$\begin{array}{c}\text { Melka- } \\
\text { Dima } \\
X \\
\text { SAB- } \\
623\end{array}$} & $\mathrm{P}_{1}$ & $249.3^{b c}$ & $223.2^{b}$ & $15.3^{b c}$ & $16.5^{\mathrm{c}}$ & $0.412^{d}$ & $0.432^{\mathrm{ab}}$ & $38.86^{b}$ & 41.04 \\
\hline & $\mathrm{P}_{2}$ & $261.6^{\mathrm{b}}$ & $204.5^{\mathrm{bc}}$ & $16.8^{\mathrm{a}}$ & $20.5^{a}$ & $0.480^{\mathrm{ab}}$ & $0.404^{\mathrm{cd}}$ & $41.79^{\mathrm{a}}$ & 44.05 \\
\hline & $\mathrm{F}_{1}$ & $295.16^{a}$ & $256.7^{\mathrm{a}}$ & $15.2^{\mathrm{bc}}$ & $17.2^{\mathrm{c}}$ & $0.499^{a}$ & $0.451^{\mathrm{a}}$ & $40.91^{\mathrm{ab}}$ & 41.93 \\
\hline & $\mathrm{F}_{2}$ & $233.5^{d}$ & $176.2^{d}$ & $15.6^{\mathrm{b}}$ & $19.6^{\mathrm{ab}}$ & $0.454^{c}$ & $0.387^{d}$ & $42.35^{\mathrm{a}}$ & 42.51 \\
\hline & $\mathrm{BC}_{1}$ & $239.9^{\mathrm{cd}}$ & $216.4^{b}$ & $14.6^{c}$ & $15.4^{d}$ & $0.430^{d}$ & $0.422^{b c}$ & $39.10^{b}$ & 41.26 \\
\hline & $\mathrm{BC}_{2}$ & $243.8^{\mathrm{cd}}$ & $187.1^{\mathrm{cd}}$ & $15.4^{b c}$ & $19.4^{\mathrm{b}}$ & $0.473^{b c}$ & $0.414^{\mathrm{bc}}$ & $40.68^{\mathrm{ab}}$ & 42.53 \\
\hline & Mean & 253.8 & 210.72 & 15.52 & 18.08 & 0.46 & 0.42 & 40.61 & 42.22 \\
\hline & LSD $_{0.05}$ & 15.32 & 19.14 & 0.92 & 1.02 & 0.02 & 0.03 & 2.35 & ns \\
\hline & CV & 3.32 & 4.92 & 3.26 & 3.09 & 2.72 & 3.25 & 3.18 & 3.47 \\
\hline
\end{tabular}

gs stomatal conductance, $\mathrm{mmol} \mathrm{m}^{-2} \mathrm{~s}^{-1}$; CT canopy temperature, ${ }^{\circ} \mathrm{C}$; Qy quantum yield; Chl chlorophyll content; $\mathrm{CV}$ coefficient of variation; LSD least significance difference; NS non-stress; DS drought stress; P1 parent 1; P2 parent 2; F1 first filial generation; F2 second filial generation; BC1 back cross 1; BC2 back cross 2; ns not significant; Means in the same column for each cross followed by similar letter are not different according to LSD test at $5 \%$ level of probability.

Drought induced decrease in stomatal conductance ranged between 8.2 (F2) and $25.3 \%$ (P2) in Roba 1 X SER-16 cross and between 9.8 (BC1) to $24.5 \%$ (F2) of Melka-Dima X SAB-623 (Table 3). The highest canopy temperature under drought stress were recorded for F2 (20.6 $\left.{ }^{\circ} \mathrm{C}\right)$ and P2 $\left(20.5^{\circ} \mathrm{C}\right)$ in Roba $1 \times$ SER-16 and Melka-Dima X SAB-623 crosses, respectively. Among the generations tested in the two crosses, the decrease in quantum yield due to drought stress was the highest for the drought resistant parents, SER-16 and SAB-623. Despite lack of differences among the generations of both crosses, there was an apparentincrease in leaf chlorophyll content by as much as $14 \%$ when the plants were subjected to drought stress.

\section{Effect of Drought Stress on Yield and Yield Components}

The effect of watering regime was significant for the number of pods per plant, seeds per pod, seed yield and harvest index. Similarly, differences among the generations of each cross and the interaction terms of watering regime and generation were significant for all yield related traits except number of seeds pod. In both crosses, drought stress imposed at flowering stage resulted in to considerable reduction in all the yield related traits (Table 4). On overall basis, drought stress reduced the number of pods per plant, seeds per pod, seed yield and harvest index by $18,8,28$ and $8 \%$, respectively relative to the non-stressed treatments.

In Roba X SER-16 cross, P2 (drought susceptible parent) suffered the highest reduction in number of pods per plant, seeds per pod, seed yield and harvest index by $37,29,58$ and $23 \%$, respectively relative to their control counterparts (Table 4). In the same cross, BC1 (SER-16X (Roba-1X SER-16)) with the least reduction in all the yield related traits was the most drought 
Abebe Hinkossa et al.,

tolerant generation. With $8.4,3.4$ and $2.8 \%$ reduction in the number of seeds per pod, seed yield and harvest index due to the drought imposed, P1 (SER-16) was the most drought tolerant generation in Melka-Dima X SAB-623 cross. On the other hand, P2 (MelkaDima) with
Sci. technol. arts Res. J., Jan-Mar 2013, 2(1): 22-31

the highest reduction in all the yield related traits was the most sensitive to drought stress. Drought induced reduction in this variety was ca. $60 \%$, which was significantly higher than the reductions recorded for the other generations in the range of 3.4 (for P1) to $37 \%$ (for BC2) (Table 4).

Table 4: Yield and yield components of six generations of two common bean crosses grown under drought stress and non-stress conditions at Melkassa, Central Rift Valley of Ethiopia.

\begin{tabular}{|c|c|c|c|c|c|c|c|c|c|}
\hline \multirow{2}{*}{ Cross } & \multirow{2}{*}{$\begin{array}{l}\text { Gene- } \\
\text { ration }\end{array}$} & \multicolumn{2}{|c|}{ NPPP } & \multicolumn{2}{|c|}{ NSPP } & \multicolumn{2}{|c|}{ SY } & \multicolumn{2}{|c|}{ HI } \\
\hline & & NS & DS & NS & DS & NS & DS & NS & DS \\
\hline \multirow{9}{*}{$\begin{array}{l}\text { Roba-1 } \\
\text { X } \\
\text { SER-16 }\end{array}$} & $\mathrm{P}_{1}$ & $31.1^{\mathrm{b}}$ & $29.2^{\mathrm{ab}}$ & 4.27 & 3.91 & $3697^{c}$ & $2817^{b}$ & $61.8^{\mathrm{ab}}$ & $60.5^{\mathrm{a}}$ \\
\hline & $\mathrm{P}_{2}$ & $34.4^{\mathrm{a}}$ & $21.7^{\mathrm{d}}$ & 4.78 & 3.39 & $4412^{a}$ & $1876^{\mathrm{e}}$ & $65.6^{a}$ & $50.6^{d}$ \\
\hline & $\mathrm{F}_{1}$ & $32.5^{\mathrm{ab}}$ & $30.2^{\mathrm{a}}$ & 3.99 & 3.75 & $3953^{b}$ & $3504^{a}$ & $62.2^{\mathrm{ab}}$ & $57.9^{\mathrm{ab}}$ \\
\hline & $\mathrm{F}_{2}$ & $29.9^{b c}$ & $24.1^{c d}$ & 3.81 & 3.44 & $2683^{e}$ & $2200^{d}$ & $56.8^{c}$ & $52.7^{\mathrm{cd}}$ \\
\hline & $\mathrm{BC}_{1}$ & $27.2^{\mathrm{c}}$ & $26.1^{b c}$ & 3.94 & 3.69 & $2896^{d}$ & $2636^{\mathrm{bc}}$ & $58.9^{\mathrm{bc}}$ & $56.7^{\mathrm{b}}$ \\
\hline & $\mathrm{BC}_{2}$ & $31.1^{\mathrm{b}}$ & $22.1^{d}$ & 4.06 & 3.74 & $3568^{c}$ & $2554^{c}$ & $60.7^{\mathrm{bc}}$ & $55.0^{\mathrm{bc}}$ \\
\hline & Mean & 31.1 & 25.6 & 4.14 & 3.65 & 3535 & 2598 & 61.1 & 55.6 \\
\hline & $\operatorname{LSD}_{0.05}$ & 2.79 & 3.49 & ns & ns & 203.4 & 228.2 & 4.89 & 3.02 \\
\hline & CV & 4.94 & 7.51 & 6.57 & 9.34 & 3.16 & 4.83 & 4.41 & 2.98 \\
\hline \multirow{9}{*}{$\begin{array}{l}\text { Melka- } \\
\text { Dima } \\
\text { X } \\
\text { SAB- } \\
623\end{array}$} & $P_{1}$ & $20.4^{\mathrm{ab}}$ & $22.27^{\mathrm{a}}$ & 3.11 & 2.85 & $4149^{c}$ & $4006^{a}$ & $60.4^{b c}$ & $58.7^{\mathrm{a}}$ \\
\hline & $\mathrm{P}_{2}$ & $22.7^{\mathrm{ab}}$ & $15.33^{c}$ & 3.19 & 2.79 & $4617^{b}$ & $1867^{d}$ & $64.3^{\mathrm{a}}$ & $54.7^{\mathrm{bc}}$ \\
\hline & $F_{1}$ & $25.7^{\mathrm{a}}$ & $19.73^{\mathrm{ab}}$ & 3.24 & 3.09 & $4173^{c}$ & $3060^{b}$ & $62.2^{\mathrm{ab}}$ & $57.5^{\mathrm{ab}}$ \\
\hline & $\mathrm{F}_{2}$ & $19.5^{b}$ & $15.53^{b c}$ & 3.14 & 3.026 & $2934^{d}$ & $1914^{d}$ & $56.3^{\mathrm{dd}}$ & $52.3^{c}$ \\
\hline & $\mathrm{BC}_{1}$ & $25.2^{\mathrm{a}}$ & $23.30^{a}$ & 3.07 & 2.81 & $4826^{a}$ & $3037^{b}$ & $59.2^{c}$ & $56.9^{\mathrm{ab}}$ \\
\hline & $\mathrm{BC}_{2}$ & $24.3^{\mathrm{a}}$ & $14.80^{\mathrm{C}}$ & 2.95 & 3.09 & $3039^{d}$ & $2300^{c}$ & $60.1^{\mathrm{bc}}$ & $55.8^{\mathrm{ab}}$ \\
\hline & Mean & 22.97 & 18.48 & 3.11 & 2.94 & 3956 & 2697 & 60.44 & 56.02 \\
\hline & $\operatorname{LSD}_{0.05}$ & 3.38 & 4.26 & ns & ns & 156.2 & 163.2 & 2.34 & 2.95 \\
\hline & CV & 8.09 & 12.69 & 11.78 & 7.99 & 2.17 & 3.32 & 2.13 & 2.9 \\
\hline
\end{tabular}

NPPP number of pod per plant; NSPP number of seed per pod; SY seed yield, $\mathrm{kg} \mathrm{ha}^{-1}$; $\mathrm{HI}$ harvest index, \%; CV coefficient of variation; LSD least significance difference; NS non-stress; DS drought stress; P1 parent 1; P2 parent 2; F1 first filial generation; F2 second filial generation; BC1 back cross 1; BC2 back cross 2; ns not significant; Means in the same column for each cross followed by similar letter are not different according to LSD test at $5 \%$ level of probability.

Based on seed yield performance, F1 and F2 generations of Roba X SER-16 were better than Melka-Dima X SAB-623 counterparts both in absolute and relative yields under drought stress. In both crosses, higher harvest indices under drought stress were maintained by drought resistant parents, SER 16 (60.5\%) and SAB-623 $(58.7 \%)$, whereas the lowest was for the susceptible parent, Roba $1(50.6 \%)$ and F2 $(52.3 \%)$ in Roba X SER-16 and Melka-Dima X SAB-623 crosses, respectively (Table 4). Seed yield of the $\mathrm{F} 2$ of both crosses under drought stress (2200 kg ha-1 for Roba X SER-16 and $1914 \mathrm{~kg} \mathrm{ha}^{-1}$ Melka-Dima X SAB-623) was much lower than the corresponding F1's (3504 kg ha ${ }^{-1}$ for Roba X SER-16 and $3060 \mathrm{~kg} \mathrm{ha}^{-1}$ for MelkaDima X SAB-623). In Melka-Dima X SAB-623, seed yield of $B C 2$ was significantly higher than
$\mathrm{BC} 1$ under both watering regimes whereas it was the reverse in Roba X SER-16 cross.

\section{Seed Yield Based Drought Indices}

The medium drought intensity index (DII) values of 0.27 (in Roba-1 X SER-16) and 0.32 (in Melka-Dima XSAB-623) crosses imply that the stress imposed was a moderate one (Table 5). On average the seed yield was reduced by $25 \%$ and $31 \%$ in Roba-1 X SER-16 \& Melka-Dima XSAB623 crosses, respectively. Percent reduction in seed yield ranged from 9 (BC1) to $57 \%(\mathrm{P} 2)$ and from 3 (P1) to 60 (P2) inRoba-1 X SER-16 and Melka-Dima XSAB-623 crosses, respectively.

The drought susceptibility index (DSI) for seed yield was high for both crosses with mean values of 0.93 and 0.97 in Roba-1 X SER-16 and MelkaDima X SAB-623 crosses, respectively. The 
Abebe Hinkossa et al.,

generations with the lowest $\mathrm{DSI}$ for seed yield were $\mathrm{BC}_{1}(0.34)$ and $\mathrm{P}_{1}(0.11)$ in Roba- 1 X SER16 and Melka-Dima $X$ SAB-623, respectively (Table 5). The geometric mean for seed yield of the six generations ranged from 2429 to 3722 in Roba-1 X SER-16 and from 2370 to 4077 in
Sci. technol. arts Res. J., Jan-Mar 2013, 2(1): 22-31

Melka-Dima X SAB-623 cross, respectively. The highest geometric mean for seed yield was recorded for $F 1$ (3722) and $P 2$ (4077) in Roba-1 $X$ SER-16 and Melka-Dima X SAB-623, respectively.

Table 5: Seed yield based drought indices in six generations of two common bean crosses grown under drought stress and non-stress conditions at Melkassa, Central Rift Valley of Ethiopia.

\begin{tabular}{cccccccc}
\hline \multirow{2}{*}{ Cross } & \multirow{2}{*}{ Generation } & \multicolumn{2}{c}{$\mathbf{S Y}\left(\mathbf{k g ~ h}^{\mathbf{- 1}}\right)$} & \multirow{2}{*}{ DII } & \multirow{2}{*}{ GM } & \multirow{2}{*}{ DSI } & \multirow{2}{*}{ PR } \\
\cline { 3 - 6 } & & $\mathbf{N S}$ & $\mathbf{D S}$ & & & & \\
\hline Roba-1 & $\mathrm{P}_{1}$ & 3697 & 2817 & 0.27 & 3227 & 0.90 & 24 \\
$\mathbf{X}$ & $\mathrm{P}_{2}$ & 4412 & 1876 & 0.27 & 2877 & 2.17 & 57 \\
SER16 & $\mathrm{F}_{1}$ & 3953 & 3504 & 0.27 & 3722 & 0.43 & 11 \\
& $\mathrm{~F}_{2}$ & 2683 & 2200 & 0.27 & 2429 & 0.68 & 18 \\
& $\mathrm{BC}_{1}$ & 2896 & 2636 & 0.27 & 2763 & 0.34 & 9 \\
& $\mathrm{BC}_{2}$ & 3568 & 2554 & 0.27 & 3018 & 1.07 & 28 \\
& $\mathrm{Mean}$ & $\mathbf{3 5 3 5}$ & $\mathbf{2 5 9 8}$ & $\mathbf{0 . 2 7}$ & $\mathbf{3 0 0 6}$ & $\mathbf{0 . 9 3}$ & $\mathbf{2 5}$ \\
\hline Melka-Dima & $\mathrm{P}_{1}$ & 4149 & 4006 & 0.32 & 4077 & 0.11 & 3 \\
$\mathbf{X}$ & $\mathrm{P}_{2}$ & 4617 & 1867 & 0.32 & 2935 & 1.87 & 60 \\
SAB 623 & $\mathrm{F}_{1}$ & 4173 & 3060 & 0.32 & 3574 & 0.84 & 27 \\
& $\mathrm{~F}_{2}$ & 2934 & 1914 & 0.32 & 2370 & 1.09 & 35 \\
& $\mathrm{BC}_{1}$ & 4826 & 3037 & 0.32 & 3828 & 1.16 & 37 \\
& $\mathrm{BC}_{2}$ & 3039 & 2300 & 0.32 & 2644 & 0.76 & 24 \\
& $\mathbf{M e a n}_{2}$ & $\mathbf{3 9 5 6}$ & $\mathbf{2 6 9 7}$ & $\mathbf{0 . 3 2}$ & $\mathbf{3 2 3 8}$ & $\mathbf{0 . 9 7}$ & $\mathbf{3 1}$ \\
\hline
\end{tabular}

NS non-stress; $D S$ drought stress; $P_{1}$ parent $1 ; P_{2}$ parent $2 ; F_{1}$ first filial generation; $F_{2}$ second filial generation; $B C_{1}$ back cross $1 ; \mathrm{BC}_{2}$ back cross 2 ; SY seed yield, $\mathrm{kg} \mathrm{ha}^{-1}$; DIl drought intensity index; GM geometric mean; DSI drought susceptibility index; PR percent reduction.

\section{DISCUSSION}

Drought induced reduction in all growth parameters found in the present study concurs previous findings in common bean subjected to different degrees of drought stress (Nielsen and Nelson 1998; Rahman \& Yahata 2007; Emam et al., 2010). In both crosses, the $F_{1}$ had the highest plant height and pod length under drought stress, which could be due to the contribution of the resistant parent. Farshadfar et al., (2008) reported similar performance of the $F_{1}$ hybrid in chick pea under drought condition. Significant decrease in leaf area of the susceptible parents could be due to an accelerated leaf senescence as well as loss of turgor. According to Gebeyehu et al. (2010), reduction in leaf area may lead to shortage of assimilate for export to and metabolism in reproductive sink organs causing significant reduction in yield. The reduction in above-ground biomass by ca. $20 \%$ in the first cross and by $33 \%$ in the second cross are ascribed to the adverse effect of drought on individual growth and yield related traits. Differences observed in drought-induced reduction in aboveground biomass of the generations are consistent with other reports, which disclosed existence of considerable genetic variation among common bean genotypes for shoot biomass accumulation when subjected to drought stress (Ramirez-Vallejo and Kelly 1998; Rosales-Serna et al., 2004).

The reduction in stomatal conductance of all the basic generations under drought stress concur with several findings on common bean grown under different intensities and timing of drought stress (Castaneda et al., 2009; Santos et al., 2009). According to De Oliveira et al., (2005), drought stress reduces stomatal conductance and transpiration rates, which often leads to high intrinsic water use efficiency in resistant varieties. The highest seed yield produced by F1 in Roba-1 $X$ SER-16 and P1 in Melka-Dima X SAB-623 cross was related to highest stomatal conductance maintained by these generations under drought stress. Relatively higher stomatal conductance allows diffusion of more $\mathrm{CO}_{2}$ into the leaf cells leading to higher rates of photosynthesis, which is positively correlated with yields of cultivars under drought situations (Fischer et al., 1998). 
Abebe Hinkossa et al.,

Canopy temperature of drought stressed plants was higher than the non-stressed plants by ca. $3{ }^{\circ} \mathrm{C}$ in both crosses. $\mathrm{BC}_{1}$ followed by $\mathrm{P}_{1}$ in Roba-1 $X$ SER-16 cross and $P_{1}$ followed by $F_{1}$ in Melka-Dima X SAB-623 cross had the lowest canopy temperature under drought stress. According to Siddique et al., (2000), plants that show a lower leaf temperature (due to lower respiration and higher transpiration rates) also show a higher photosynthetic rate, which appears to be the case for the resistant parents and $\mathrm{BC}_{1}$ and $F_{1}$ generations, which produced relatively higher biomass and seed yield under drought stress. The highest increase in leaf chlorophyll content due to drought stress in the susceptible parents of the two crosses (Roba-1 and MelkaDima) were associated with the considerable decrease in their leaf area in response to the stress imposed. Increased leaf chlorophyll content due to moderate stress may result from increased specific leaf area and reduced leaf area due to reduced size of new cells (Makhdum et al., 2004; Taiz and Zeige, 2006).

Quantum yield also decreased under drought compared with non-stress condition. The reduction was more pronounced in the susceptible cultivars (Roba-1 and Melka-Dima) and $F_{2}$ generations of the two populations. The lowest reduction was observed in resistant cultivars (SER-16 and SAB-623) followed by their back crosses $\left(B_{1}\right)$ (Table 3$)$. Such pronounced effect of drought stress on quantum yield of susceptible cultivars has been reported for wheat (Subrahmanyam et al., 2006) and common bean (Terzi et al., 2010). Generally, decreases in Photosystem II quantum yield can result from the photo-protective increase in non-photochemical quenching (Demming and Adams, 1996). Thus, lowest reduction in quantum yield of resistant parents implies that their photosynthetic apparatus was more protected than the susceptible parents when subjected drought stress.

Significant differences in yield related traits among the basic generations under the contrasting soil moisture regimes are similar to the results reported on chickpea (Farshadfar et al., 2008), indicating the existence of genetic variation between the parent varieties and the possibility of selection for drought resistance. In Roba-1 X SER-16 cross, mean performance of $F_{1}$ under non-stress condition was in between the two parents whereas the performance of the same generation under drought stress exceeded that of both parents, indicating existence of hetrosis for yield and yield components under the
Sci. technol. arts Res. J., Jan-Mar 2013, 2(1): 22-31

stress condition imposed. On the other hand, the $F_{2}$ mean was lower than the $F_{1}$ signifying the presence of inbreeding depression. The $F_{2}$ population had the lowest seed yield and this could be attributed to segregation (independent assortment) of the genes into various genotypes including recombinants with low yield potential. Mean performance $\mathrm{BC}_{1}$ was lower than $\mathrm{BC}_{2}$ under non-stress condition and conversely $\mathrm{BC} 1$ performed better than $\mathrm{BC}_{2}$ under drought stress in Roba-1 X SER-16 cross. In Melka-Dima $X$ $\mathrm{SAB}-623, \mathrm{BC}_{1}$ performed better than $\mathrm{BC}_{2}$ under both growth conditions, for most of the traits including seed yield. Conversely, although differences for pod per plant, seed per plant and harvest index were non-significant under nonstress condition. In Melka-Dima X SAB-623 cross, SAB-623 and its $F_{1}$ and $B_{1}$, exhibited superior performance to the susceptible parent (MelkaDima) in all yield related characters under drought stress. The resistant parents produced higher yield under drought conditions through maintaining higher seed per plant and above ground biomass, which can be used as selection criteria for developing common beans varieties adapted to drought conditions in the central rift valley of Ethiopia.

Drought induced reduction in seed yield of all generations was on the account of the adverse effect of the stress on the yield components considered, number of pods per plant, seeds per pod and harvest index. Similar findings have previously been reported for the crop (Acosta et al., 2004; Munoz-Perea et al., 2006; GhassemiGolezeni and Mardaf, 2008). Differences in yield among the generations (and the parents, in particular) of both crosses under drought conditions confirmed the degrees of resistance inherent to the genotypes. The most adverse effect of the stress among the yield components was on the number of pods per plant. This is in agreement with the findings of Nunez-Barrios et al., (2005) that a yield reduction due to drought stress by about $60 \%$ in dry bean was attributed to losses of $63.3 \%$ in pods per plant, $28.9 \%$ in seeds per pod, and $22.3 \%$ in seed weight. The highest geometric mean for seed yield was recorded for F1 (3721.8) and P2 (4077.1) in Roba-1 X SER-16 and Melka-Dima X SAB-623, respectively. According to Porch et al., (2009), geometric mean was the best seed yield-based drought index which helped in the identification of superior common bean genotypes that performed well under different soil moisture regimes and thus may serve as criteria for drought improvement and genetic analysis. 
Abebe Hinkossa et al.,

\section{CONCLUSION}

Significant differences found among the basic generations and their differential response to the contrasting soil moisture regimes indicated the existence of variation among the parental varieties and the potential of screening for drought in selecting varieties adapted to moisture-limited environments. Drought stress imposed at flowering stage reduced all growth, physiological and yield related traits of the basic generations of both crosses. On average drought-induced seed yield reductions were $25 \%$ and $31 \%$ for Roba-1 X SER-16 and Melka-Dima $X$ SAB-623 crosses, respectively. Among the generation tested, the two drought resistant parents (SER-16 and SAB-623) and their $F_{1}$ and $B C_{1}$ generated from crossing with the other parents were outstanding in their adaptation to drought stress condition. The superior performance of these generations was associated with higher stomatal conductance, leaf area, aboveground biomass yield and greater ability to remobilize biomass to reproductive sinks under drought stress.

\section{ACKNOWLEDGEMENTS}

We thank the Ministry of Education of Ethiopia for the financial support. We are also grateful to Melkassa Agricultural Research Center for providing the germplasm and experimental facilities. The technical support of staff of the National Bean Research Program of Ethiopia is duly acknowledged.

\section{REFERENCES}

Abebe, A., Brick, M.A. and Kirkby, R. (1998). Comparison of selection induces to identify productive dry lines under diverse environmental conditions. Field Crops Research, 58, 15-23.

Acosta, D.E., Acosta-Gallegos, J.A.A. and Padilla, R.J.S. (2004). Relaciónraíz-vástago en frijol bajo dos condiciones de humedad. Agricultural Science and Técnology in México, 30, 63-73.

Assefa, H. (1994). Epidemiology of bean rust in Ethiopia. Ph.D Thesis. Wageningen University. The Netherlands.

Beebe, S.E., Rao, I.M., Cajiao, C. and Grajales, M. (2008). Selection for drought resistance in common bean also improves yield in phosphorus limited and favorable environments. Crop Science, 48, 582-92.

Blum, A. (2005). Drought resistance, water use efficiency, and yield potential are they compatible, dissonant, or mutually exclusive? Australian Journal of Agricultural Research, 56, 1159-1168.
Sci. technol. arts Res. J., Jan-Mar 2013, 2(1): 22-31

Castaneda-Saucedo, M.C., Cordova-Tellez, L., Gonzalez-Hernandez, V.A., Delgado-Alvardo, A., Santacruz-Varela, A. and Santos, G.G. (2009). Physiological performance, yield, and quality of dry beans under drought conditions. Interciencia, 34(10), 748-754.

Demming-Adams, B. and Adams, W.W. (1996). Xanthophyll cycle and light stress in nature: uniform response to excess direct sunlight among higher plant species. Planta, 198, 460-470.

De Oliveira, A., Fernandes, E.J. and Rodrigues, T.J.D. (2005). Conductanciaestomatica Como Indicador de estressehidricoem Feijao. Engineering in Agriculture Jaboticabal, 25, 86-95.

Emam, Y., Shekoofa, A., Salehi, F and Jalali, A.H. (2010). Water stress effects on two common bean cultivars with contrasting growth habits. AmericanEurasian Journal of Agricultural \& Environmental Sciences, 9(5), 495-499.

Farshadfar, E., Sabaghpour, S.H. and Khaksar, N. (2008). Inheritance of drought tolerance in chickpea (Cicerarietinum L.) using joint scaling test. Journal of Applied Sciences, 8, 3931-3937.

Fischer, R.A., Rees, D., Sayre, K.D., Lu, Z.M., Condon, A.G. and Larque Saavedra, A. (1998).Wheat yield progress associated with higher stomatal conductance and photosynthetic rate and cooler canopies. Crop Science, 38, 467-1475.

Gebeyehu, S., Wiese, H., Schubert, S. (2010). The effects of drought stress on assimilate availability and metabolism in the source and sink organs of common bean (Phaseolus vulgaris L) genotypes. Ethiopian Journal of Agricultural Science, 20, 4763.

Ghassemi-Golezeni, K. and Mardfar, R.A. (2008). Effect of Limited Irrigation on Growth and Grain yield of Common bean. Journal of Plant Sciences, $3(3), 230-235$.

Gomez, A.K and Gomez, A.A. (1984). Statistical Procedures for Agricultural Research. $2^{\text {nd }}$ edition. John Wiley and Sons, New York.

Khaghani, S., Bihamta, M.R., Hosseini, S.D., Mohammadi, S.S., Darvish, F. (2012). Genetic analysis of common bean agronomic traits in stress and non-stress conditions. African Journal Agricultural Research, 7(6), 892-901.

Makhdum, M.I., Malik, M.N.A., Din, S.U., Ahmad, F. and Chaudhry, F.I. (2002). Physiological response of cotton to methanol foliar application. Journal of Research (Science), 13, 37-43.

Mitra, J. (2001). Genetics and genetic improvement of drought resistance in crop plants. Current Science, 80, 758-763.

Munir, M., Chowdhry, M.A. and Ahsan, M. (2007). Generation means studies in bread wheat under drought condition. International Journal of Agriculture and Biology, 9(2), 282-286. 


\section{Abebe Hinkossa et al.,}

Munoz-Perea, C.G., Terán, H. Allen, R.G., Wright, J.L., Westermann, D.T. and Singh, S.P. (2006). Selection for drought resistance in dry bean landraces and cultivars. Crop Sciences, 46, 21112120.

Nielsen, D.C and Nelson, N.C. (1998). Black bean sensitivity to water stress at various growth stages. Crop Sciences, 38, 422-427.

Nunez-Barrios, A., Hoogenboom, G. and Nesmith, D.S. (2005). Drought stress and the distribution of vegetative and reproductive traits of a bean cultivar. Scientia Agricola, 62,18-22.

Porch, T.G., Ramirez, V.H., Santana, D. and Harmsen, T. (2009). Evaluation of Common Bean for Drought Tolerance in Juana Diaz, Puerto Rico. Journal of Agro Crop Science, 195, 328-334.

Rahman, M. A., and Yahata, H. (2007). Effect of Mulch and Irrigation on Leaf water Relation and Pod yield of Common Bean in Dry period of Bangladesh. International Agricultural Research, 2(10), 862-869.

Ramirez-Vallejo, P. and Kelly, J.D. (1998). Traits related to drought resistance in common bean. Euphytica, 99, 127-136.

Reynolds, M.P. and Trethowan, R.M. (2007). Physiological interventions in breeding for adaptation to abiotic stress. In: Spiertz, J.H.J., Struik, P.C. and Van Laar, H.H (eds.), Scale and Complexity in Plant Systems Research: GenePlant-Crop Relations, 129-146.
Sci. technol. arts Res. J., Jan-Mar 2013, 2(1): 22-31

Rosales-Serna, R., Kohashi-Shibata, J., AcostaGallegos, J.A., Trejo-Lopez, C., Ortizcereceres, J. and Kelly, J. (2004). Biomass distribution, Maturity acceleration and yield in Drought- stressed Common bean Cultivars. Field Crops Research, 85, 203-211.

Santos, M.G., Ribeiro, R.V., Machado, E.C. and Pimentel, C. (2009). Photosynthetic parameters and leaf water potential of five common bean genotypes under mild water deficit. Biologia Plantarum, 53(2), 229-236.

Siddique, M.R.B., Hamid, A and Islam, M.S. (2011). Drought stress effects on water relations of wheat. Botanical Bulletin of Academia Sinica 41, 35-39.

Subbarao, G.V., Johansen, C., Slinkhard, A.E., Nageswara Rao, R.C., Saxena, N.P. and Chauhan, Y.S. (1995). Strategies for improving drought resistance in grain legumes. Critical Reviews in Plant Sciences, 14, 469-523.

Taiz, L. and Zeiger, E. (2006). Plant Physiology. $3^{\text {rd }}$ Ed., Sinauer Associates, Sunderland, MA, pp: 705.

Teran, H. and Singh, S.P. (2002). Comparison of sources and lines selected for drought resistance in common bean. Crop Science, 42, 64-70.

Terzi, R., Saglam, A., Kutlu, N., Nar, H. and Kadioglu, A. (2010). Impact of soil drought stress on photochemical efficiency of photo system II and antioxidant enzyme activities of Phaseolus vulgaris cultivars. Turkish Journal of Botany, 34, 1-10. 